\title{
Immigrant students' shifting identifications in South African schools
}

\author{
Saloshna Vandeyar \\ University of Pretoria, Faculty of Education, Department of Humanities Education, Pretoria, 0002, South Africa
}

A R T I C L E I N F O

\section{Keywords:}

Immigrant students

Identities

Agency

Race

Culture

\begin{abstract}
A B S T R A C T
The easing of legal and unauthorized entry to South Africa has made the country a new destination for Black immigrants. As this population continues to grow, its children have begun to experience South African schools in an array of uniquely challenging ways. For these immigrant youth, forging a sense of identity may be their single greatest challenge. There is however, very little research on the ways in which immigrant student identities are framed, challenged, asserted and negotiated in South African schools. Accordingly, this study asks how do immigrant students speak about their identifications in light of their negotiation of the school and social spaces in South Africa. Utilising the theoretical frameworks of understanding immigrant identities and identity pathways, this research study attempts to understand the unique experiences of Black immigrant youth inside South African schools. Findings were multi-fold in nature. First, although immigrant students' ease of assimilation into the chosen reference group was to some degree sanctioned by their phenotypic racial features, their attempt at 'psychosocial passing' was politically motivated. Second, immigrant students did not readily classify according to skin pigmentocracy. Third, the majority of immigrant students heightened their ethnic selfawareness in forming their identity, but also assumed hyphenated identities. Fourth, immigrant students were not seen as having an identity, but rather as being 'plugged into a category with associated characteristics or features'. Fifth immigrant students forged a 'continental identity'. And sixth, the selfagency of immigrant students was twofold in nature; not only did they want to improve their own condition, but there seemed to be an inherent drive to improve the human condition of others.
\end{abstract}

(c) 2011 Elsevier Ltd. All rights reserved.
Identities are the names we give the different ways that we are positioned by, and position ourselves within the narratives of the past. (Hall).

\section{Introduction}

The demise of formal apartheid has created new and as yet only partially understood opportunities for migration in South Africa. One of the most notable post-apartheid shifts is the sheer volume and diversity of human traffic now crossing South Africa's borders. South Africa is increasingly host to a truly pan-African and global constituency of legal and undocumented migrants. Legal migration from other Southern African Development Community (SADC) countries, for example, increased almost 10-fold since 1990 to over four million visitors per year. South Africa's (re)insertion into the global economy has also brought new streams of legal and undocumented migrants from outside the SADC region and new ethnic constellations within. The easing of legal and unauthorized entry to South Africa has made the country a new destination for African asylum-seekers, long-distance traders, entrepreneurs,

E-mail address: saloshna.vandeyar@up.ac.za. students and professionals (Bouillon, 1998; Saasa, 1996; Rogerson, 1997; De la Hunt, 1998; Peberdy and Crush, 1998; Ramphele, 1999; Klotz, 2000). Consequently, traditional forms of migration are being reconfigured and new forms of migrant linkage are emerging with traditional neighbours (Crush and McDonald, 2000). These reconfigured and new forms of migrant linkages hold serious implications for immigrant children in South African schools as the dynamics of belonging are nowhere as harsh as it is, than in the day-to-day activities on the classroom floor and in the schoolyard.

Many scholars claim that the structure of immigrant students' journeys into their new homes follows multiple pathways that are motivated by a variety of factors, namely, relief from political, religious or ethnic persecution; economic incentives; as well as the opportunity to be reunited with family members (Berry, 1997; Suarez-Orozco and Suarez-Orozco, 2001). Furthermore, these scholars argue that immigrant students are stripped of many of their sustaining social relationships as well as the social roles that provide them with culturally scripted notions of how they fit into the world, which often results in acculturative stress (Berry, 1997; Suarez-Orozco and Suarez-Orozco, 2001). Forging a sense of identity for these youth may be their single greatest challenge. In this regard, Suarez-Orozco (2004:176) poses some pertinent 
questions that have a direct bearing on this study: "Do they feel comfortable in their homeland? Do they feel accepted by the "native-born" of the host country? What relationship do they have with their parents' country of origin? Is their sense of identity rooted "here", "there", "everywhere" or "nowhere"? How do they forge collective identities that honour both their parents' culture of origin as well as their new home in South Africa? How can they develop a sense of belonging while coping with the dissonance of "excluded citizenship?"

Since the advent of democracy, most public schools in South Africa in addition to opening their doors to all South African children irrespective of race, colour or creed, have also opened their doors to a number of [black] immigrant children. There is however, very little research on the ways in which immigrant student identities are framed, challenged, asserted and negotiated within the dominant institutional cultures of schools. Accordingly, this study asks how do immigrant students speak about their identifications in light of their negotiation of the school and social spaces in South Africa.

The argument is presented as follows. I begin by sketching the background context of the study. This is followed by a review of literature that informs research on immigrant students' identities. Theoretical groundings of this research study are subsequently presented. I then describe the design and sampling of this research study. Findings in the form of emergent themes from interviews and observations of immigrant students are then presented. I conclude with an analysis and discussion of findings and examine ways in which immigrant students identify in schools and social spaces of South Africa.

\section{Background context}

To date studies in this field have focused mainly on black and white dynamics of South African students. There is very little, if any research on the experiences of [black] immigrant students within South African schools. In much of the research on hybridity and transculturalisation, the important role of schooling as a mediating force in identity-making processes has also received little attention. Schools through both formal and informal relationships, represent powerful interpretations of what it means to be "South African", "Mozambican" or "Zimbabwean" that is of belonging and non-belonging. This research study sets out to explore how [black] immigrant students identify in schools and social spaces in South Africa. The context of this study was limited to the Gauteng ${ }^{1}$ province of South Africa.

The central cities of Gauteng have some of the largest numbers of Black immigrants, who are diverse not only in terms of national origin, but by ethnic affiliation, cultural tradition, and generational status. The majority of Black immigrants in the Gauteng province of South Africa are from Mozambique, Lesotho, Zimbabwe, Democratic Republic of Congo, Swaziland, Botswana, Angola and Malawi, but substantial numbers of immigrants also come from Zambia, Pakistan, Nigeria, Namibia, India, Kenya, Somalia, Uganda, Ruwanda, Etopia, SriLanka, Tanzania and Mauritius (Gauteng Department of Education, Ten Day Statistics, 2008). As this population continues to grow, its children have begun to experience South African schools in an array of uniquely challenging ways. As a result of these demographic trends, researchers have increased their focus on how Black immigrant youth fare once in South African schools.

Some of the data capture of this research study occurred during the height of the xenophobic attacks in South Africa (Hassim et al., 2008; Coplan, 2008). Larger societal tension fuelled by sensationalistic media attention had much more saliency in

${ }^{1}$ Gauteng - one of the nine provinces of South Africa. the formation of immigrant student identities and in everyday interactions between South African and immigrant students at schools. The perpetrators of the violence in May explicitly targeted the makwerekwere ${ }^{2}$ These xenophobic attacks illustrated violent verbal and physical acts being directed towards Black immigrants by their Black South African counterparts who often erroneously perceive their Black immigrant peers' lack of familiarity with so-called "South African norms" as intentionally distancing themselves from Black South Africans and related anti-Black South African arrogance. This 'shack on shack violence' (Hassim et al., 2008:16) was distinctive in several respects (Verryn, 2008). First, the attacks were on black foreign nationals. There is no record as far as any whites or Indians being caught up in these attacks. Second, it was mainly the poorer and more vulnerable foreign nationals that were exposed to the most vicious onslaught. Third, at least a third of the people killed were South African. And fourth, the violence was visited on the particularly marginalised of society, taking on ethnic and xenophobic connotations.

\section{The architecture of identity}

\subsection{Theorizing identity}

A number of scholars claim that identity goes through a variety of permutations during adolescence as the individual experiments with different identity strategies (Phinney and Ong, 2007; Suarez-Orozco, 2004; Sirin and Fine, 2008; Murrell, 1999; Marcia et al., 1993; Marcia, 1980; Parham, 1989). Some argue that all youth move steadily from a stage of ethnic or 'racial unawareness' to one of 'exploration' to a final stage of an 'achieved' sense of racial or ethnic identity (Marcia, 1966; Erickson, 1968). Others point out that the process of identity formation is, rather than being linear, more accurately described as 'spiralling' back to revisit previous stages, each time from a different vantage point (Parham, 1989). Yet, others claim that identity is "an internal self-constructed, dynamic organisation of drives, abilities, beliefs and individual history" (Marcia, 1980:159), which facilitates psychological differentiation from others. A sense of emerging identity characterised by 'a flexible unity', that makes an individual less likely to rely on others views and expectations for self-definition.

Suarez-Orozco (2004:177) challenges the view held by Erikson and argues that identity formation is not simply a process by which one passes through a variety of stages on the way to achieving a stable identity. Rather it is a process that is fluid and contextually driven. The social context is essential in predicting which identity is constructed (Suarez-Orozco, 2000). Many immigrant youth today are articulating and performing complex multiple identifications that involve bringing together disparate cultural streams. Immigrant students are constantly reinventing and rediscovering themselves through interactions in social structures, particularly peer reference groups and institutionally circumscribed roles, values and ideologies. Among these social worlds inconsistencies in the codes, values, roles, or expectations add to the difficulty of identity development.

Identity is thus 'socially constructed'. It is an interaction between an internal psychological process and external process of categorisation and evaluation imposed by others. The social context is thus essential in predicting which identity is constructed (Suarez-Orozco, 2000).

\footnotetext{
${ }^{2}$ Makwerekwere - people who were identified as not properly belonging to the South African nation. Makwerekwere is the derogatory term used by Black South Africans to describe non-South African blacks. It refers to Black immigrants from the rest of Africa.
} 


\subsection{Negotiating the currents of a complex society}

Negotiating the currents of identities for immigrant students can be particularly complex. The pathways they take, and the identities they form are determined in multiple ways. Resources, experiences, stresses and trauma as well as the coping strategies they bring with them play a key role. Critical to the formation of their identities is the structural and attitudinal environment within which they find themselves (Suarez-Orozco and SuarezOrozco, 2001; Taylor, 1994). Immigrant students must not only deal with aspects of personal development shared by all adolescents (relationships, work choices, examining values) but also often confront culture-related differences concerning these choices. They must also seek to create a sense of identity through personal choices surrounding relationships, occupation, worldviews and values which sometimes may conflict with parental and other family expectations (Murrell, 1999; Dion, 2006).

Erickson (1968) argued that the single greatest developmental task of adolescence is to forge a coherent sense of identity. Optimal development in this regard, would require a certain amount of complementarity between the individual's sense of self and the varied social milieus he/she must traverse. However, in an increasingly fractured, heterogeneous transnational world, there is much less complementarity between social spaces (SuarezOrozco, 2000). The ethos of reception plays a critical role in the adaptation of immigrant students (Suarez-Orozco and SuarezOrozco, 2001). Although the structural exclusion suffered by immigrants and their children is tangibly detrimental to their ability to participate in the opportunity structure, prejudicial attitudes and psychological violence also play a toxic role (Taylor, 1994).

One of the ways in which this plays out is that of the social mirror (Suarez-Orozco, 2000). When the reflected image is generally positive, the individual is able to feel that she is worthwhile and competent. When the reflection is generally negative, it is extremely difficult to maintain an unblemished sense of self-worth. The social mirror creates the fertile conditions for what Du Bois (1903/1989) termed “double-consciousness" to thrive.

'Double-consciousness' is a complex and constant play between the exclusionary conditions of social structure marked by race and the psychological and cultural strategies employed by the racially excluded and marginalised to accommodate themselves to every indignities as well as to resist them (Essed and Goldberg, 2002).

'Psychosocial passing' (Berry, 1997; Nesdale et al., 1997; Suarez-Orozco, 2000) is one way of overcoming the effects of the social mirror. Psychosocial passing refers to people who seek to render invisible the visible differences between themselves and a desired or chosen reference group. By behaving in ways that are consistent with other group members, they subconsciously seek to avoid having their differences noticed. Phenotypic racial features have considerable implications for the ease of assimilation. In this era of globalisation immigrants ability to 'pass' or be fully assimilated unnoticed is no longer possible for most new arrivals and this can lead to undue stress (Berry, 1997; De Vos, 1980; Suarez-Orozco, 2000).

Within the context of social worlds, identities of immigrant students manifest themselves in numerous and multiple forms namely, Achieved or an Ascribed [imposed] identities (SuarezOrozco, 2004; Suarez-Orozco and Suarez-Orozco, 2001; SuarezOrozco, 2000; Helms, 1990; De Vos, 1980); Performing Identities (Maestes, 2000; Waters, 1990); Global Identity (Arnett, 2002); Dominating identities (Murrell, 1999); Ethnic Identities (Phinney \&
Ong, 2007) and Hyphenating and perforating identities (Sirin and Fine, 2008).

\section{Theoretical moorings}

\subsection{Understanding immigrant identities}

An influential framework for understanding immigrant identity was developed by Berry $(1974,1980,1997)$. This framework proposed that two important dimensions came into play in the construction of identities namely, the home culture and the host culture. In this framework, two issues are raised: the degree to which people wish to maintain their heritage culture and identity; and the degree to which people seek involvement with the larger society. When these two issues are crossed, an acculturation space is created with four sectors within which individuals may express how they are seeking to acculturate. The motivation of an immigrant to acculturate to the host society and culture is largely dependent on the value that such acculturation holds for him/her. The immigrant individual tries to negotiate a balance by establishing relationships with the dominant society while simultaneously maintaining his/her ethnic identity and cultural characteristics. The negotiation between these choices gives rise to immigrant's adaptation and identity development. These four sectors of adaptation are namely: (1) assimilation, whereby the immigrant student forsakes his/her culture and adopts the dominant culture. (2) Integration, where the immigrant student maintains his/her own culture and adopts aspects of the dominant culture. (3) Separation, where the immigrant student maintains his/her culture and does not adopt the culture of the dominant group. (4) Marginalisation, where the immigrant student neither adopts the dominant culture nor maintains his/her own culture. Seminal works in the field indicate that maintaining a balance between the home and host cultures, while holding a positive attitude towards both groups, can foster immigrant students' development of a healthy sense of self that leads to positive educational outcomes (Berry, 1997; Suarez-Orozco, 2004; Phinney and Ong, 2007). Furthermore, these scholars argue that the maintenance of home language serves as an avenue for immigrant students to access social support from both the family and the broader community, especially in the case of non-English speaking immigrant families and communities.

\subsection{Identity pathways}

Identity pathways or styles of adaptation of immigrant students differ. Suarez-Orozco and Suarez-Orozco (1995) noted that youth attempting to transverse discontinuous cultural, political and economic spaces tended to gravitate towards one of the dominant styles of adaptation namely, 'ethnic flight', 'adversarial', 'bicultural' and 'transcultural'. 'Ethnic flight' is characterised by immigrant students who willingly attempt to symbolically and psychologically dissemble and gain distance from their families and ethnic groups. The 'adversarial style' is characterised by immigrant students who structure their identities around a process of rejection by institutions of the dominant culture. These youths respond to negative social mirroring by developing a defensively oppositional attitude and are likely to act out behaviourally (Aronowitz, 1984; Garcia-Coll and Magnuson, 1997). The 'bi-cultural style' deploys what is termed 'transnational strategies'. These children typically emerge as 'cultural brokers' mediating the often conflicting cultural currents of home culture and host culture (Suarez-Orozco, 1989; Suarez-Orozco and SuarezOrozco, 1995). The 'transcultural style' is characterised by youth who creatively fuse aspects of two or more cultures - the parental tradition and the new cultures. In so doing, they synthesize an 
identity that does not require them to choose between cultures but rather allows them to incorporate traits of different cultures while fusing additive elements (Falicov, 2002).

\section{Research strategy}

The research study was both exploratory and descriptive in nature. The overall school environment with particular reference to how immigrant students speak about their identifications in light of their negotiation of the school and social spaces in South Africa was the unit of analysis. Particular emphasis was placed on the dynamics of institutional culture and the climate of the school and the classroom. The research design was qualitative in nature and the narrative method and case study approach was used.

Three secondary schools located in the Gauteng province of South Africa provide the research sites for this study; a former white Model C school, a former Indian school and an inner city school that had a majority of black African learners. The rationale for selecting secondary school students is that these students are at the adolescent stage of their lives, where the self-creation of one's identity, which is often triggered by biological changes associated with puberty, the maturation of cognitive abilities and changing societal expectations and the process of simultaneous reflection and observation is commonly experienced (Tatum, 1997). Criteria used in the selection of students were based on racial background and gender.

The data gathering techniques that were used in this study included a mix of semi-structured interviews, observation and field notes. Semi-structured interviews were conducted with a purposive sample of immigrant students to determine how their identities are constituted, negotiated and represented in schools. The researcher selected approximately 15 [black] immigrant students (Lesotho, Kenya, Nigeria, Malawi, Congo, Zimbabwe, Mozambique, India, Pakistan, Sri Lanka) across Grades 8-10 at each school. The selection of immigrant students depended on the mixture that we found at each of the identified schools. An attempt was made to include both Anglophone and Francophone immigrant students in this study. A total of 45 students were interviewed. These interviews were conducted in 2008 over a period of six months. Questions comprised of five to six broad categories and were open-ended. The duration of interviews ranged between 1 and $2 \mathrm{~h}$. All interviews were recorded and transcribed.

Semi-structured interviews were conducted with the principal, the School Management Team, the School Governing Body, selected teachers of these Grades (8-10) and parents of immigrant children at each of the three research sites to explore the phenomenon of immigrant student identities.

Observations were conducted to coincide with the interview period. Researchers observed immigrant students over a period of six weeks at each school with a focus on their experiences of school life and how it plays out on the classroom floor and the school grounds. Observations of classroom practice, activities and associations during the break sessions, assemblies and other activities of the school including after school activities were captured. It must however be noted that there are advantages and limitations of observations at a small number of schools. The advantages of such a technique is that it provides a lens into the 'lived experiences' of classroom life over a period of time that allows for in-depth study and creates the opportunity for patterns (if any) to emerge. The limitation is that the small number of schools observations could be seen as instructive and illustrative, and not as representative of all schools.

In order to get a better feel of the schooling and learning environment, various field notes were written, based on informal observations of these schools (ethos, culture and practices of the school). Informal conversations were conducted with some teachers. Attention was also given to the physical appearance of the school, which included observations of artefacts such as paintings, décor, photographs, portraits and school magazines to provide a sense of the institutional culture of the school. Do immigrant students feel a sense of belonging and being at home at the school? Particular emphasis was on the experiences of immigrant students and how they tried to negotiate a balance by establishing relationships with the dominant society and simultaneously maintaining their own ethnic identity and cultural characteristics.

Data was analysed utilising qualitative content analysis (Mayring, 2000; Sandelowski, 2000). Codes were generated from the data and continuously modified by the researcher's treatment of the data "to accommodate new data and new insights about those data" (Sandelowski, 2000:338). This was a reflexive and an interactive process that yielded extensive codes and themes. The extensive codes were further analysed to identify data related to key concepts in the research question, theoretical frameworks, and literature review (Miles and Huberman, 1994). Multiple readings of the data were conducted, organizing codes and themes into higher levels of categories within and across the interviews, observations, and other sources of data (Merriam, 1998).

\section{Findings}

Major findings that contrasted with what was found in the voluminous literature in this field were multi-fold in nature. First, although immigrant students' ease of assimilation into the chosen reference group was to some degree sanctioned by their phenotypic racial features, their attempt at 'psychosocial passing' (Robinson, 1999) was politically motivated. They claimed that because of the political status of the host country, it was in their interest to 'pass' as local blacks, but they wanted to do this in terms of appearance only and nothing else. For many immigrant students the behaviour and code of conduct of their local black peers in the host country represented a site of contamination and shame.

The concept of 'passing' within the black community in the western world traditionally referred to blacks who pass for white because of their light skin colour. However, in the South African context this concept refers to black immigrant students who 'pass' for local black students because of similar phenotypic racialised features.

I can honestly say, I have not once noticed that the girls treat them any differently to a South African Zulu girl or a South African Xhosa girl or a South African Sotho girl, they look the same. It is really difficult to tell them apart physically (Ms Wilson, Grade 10 teacher).

They don't really react badly because they say I look mostly like a South African, like a Venda. I don't look like a foreigner. I mean I look like a Venda. So when I tell them I am from another country they actually get surprised (Effi, Zambia).

I fit in well, like the other South African Indians in this school. I speak English well, I don't really have an 'Indian' accent so I am like one of them (Jeet, Pakistan).

Well they didn't really see me as an immigrant I was just like one of them. So I just let them go on believing that I am one of them. I don't let them know that I am really an immigrant (Vena, Zimbabwean).

The ability to join the mainstream unnoticed is more challenging when one is racially marked. However, in the South 
African context the most discernible marker among black immigrant students was not one of race, but that of language and accent. In the case of black [African] immigrant students it was their lack of proficiency in indigenous languages that signalled their 'foreignness'. Whereas with black [Indian] immigrant students, it was their lack of proficiency in English that made them conspicuous as foreigners. In both cases 'accent' in the use of the English language was the critical signifier of the 'Other'. A secondary instantaneous indicator was that of 'shades of blackness'. Indigenous black students could immediately recognise black [African] immigrant students by the 'blackness of their skin pigmentation'. Wu (2002) argues that immigrants ability to 'pass' or be fully assimilated unnoticed is no longer possible for most new arrivals in this era of globalisation.

Kevin, a Zimbabwean who could physically identify with the local black students because of a similar 'shade of blackness', tried to desperately 'pass' as one of them by addressing his shortcoming in terms of learning an indigenous language. He claims,

I do not want to be identified by my culture. I look like South African black people. I have made an effort to learn Sepedi to try to fit in and to communicate with the local blacks so that they do not say I am a makwerekwere.

Immigrant students chose varied ways to present and orientate themselves in relation to others in the host country. What is important to note is that although the phenotypic features of many immigrant students allowed them to 'pass' for one of the local blacks, all immigrant students were resolute in maintaining their sense of moral integrity.

Second immigrant students did not readily classify themselves according to skin pigmentocracy. They initially identified themselves in terms of personality traits and subsequently in terms of ethnicity linked to culture, traditions, language and country of origin. The label of 'Black' was something that was ascribed to them on entry into the host country and something that they learnt to incorporate as part of their identity, given that they shared similar phenotype features as indigenous black students, as evident from this vignette.

Interviewer: $\quad$ Would you class yourself according to colour? Immigrant: Yes.

Interviewer: Who would you say you are?

Immigrant: I'm black; I'm African.

Interviewer: Why do you say you are an African?

Immigrant: Because I originate from Africa.

Interviewer: And why do you call yourself black?

Immigrant: Because that's how we're classified by the South African government.

Interviewer: And are you happy with that?

Immigrant: $\quad$ Not really, because I've heard so many people complain about being called black because our skin colour is naturally black.

Interviewer: $\quad$ So you won't classify yourself as black in Zambia?

Immigrant: $\quad$ Me, no, no, no definitely not! I was not identified as 'black' in Zambia,but, here I am told that I am 'black' because I look more like the local black Africans than like the Indians and whites.

Interviewer: In Zambia, how would you classify yourself? Immigrant: As African.
Interviewer:

Just African?

Immigrant: $\quad$ Yes. It is only when I came to South Africa that I realized that I've got another label, now I am a black African.

Interviewer: How does this make you feel?

Immigrant: I feel bad because I am not 'black' I am 'African'... because I come from Africa. "I am not happy about being called black. I prefer being called African'. Also, my culture is totally different from theirs [black South Africans] and in my culture we are taught to respect and behave well. We also dress differently. There are so many differences with them so how can people see me like one of them? I am just an African student in South Africa from Zambia... all these other labels; black and all that doesn't get into my identity.

And another student's response,

In Burundi we just say our culture and language, but when I came to South Africa I learnt that I am now 'black' (Andrew, Ghana).

I am Zimbabwean and I'm black and I speak Kalanga. . .I say I am 'black' because when I came to South Africa I was told by the learners, teachers and the principal that I am black and I could also see that I look like the 'black South Africans'. No, in Zimbabwe I was not 'black'. I was just from the Kalanga tribe (Vena, Zimbabwean)

Third, the majority of immigrant students heightened their ethnic self-awareness in forming their identity, but also assumed hyphenated identities, as much as the hyphen was heavily skewed in favour of the country of origin. Immigrant students negotiated the balance and contours of the hyphen as they navigated their way through the social contexts of the host country.

I am Rwandan, but I am living now for 12 years in South Africa, so I'd say I am Rwandan but also becoming South African. I am a Rwandan-South African (Belice, Rwandan).

[Sighs] I don't... I wouldn't say I'm a foreigner, no. I am a Congolese- South African, yes. I'm... who I am is two different cultures that play a huge, huge, impact on me and sadly I'm going say it's more South African than Congolese people that have made me who I am. But because culture means a lot to me, I have to say I am Congolese-South African (Vanessa, DRC).

Fourth, immigrant students were not seen as having an identity, but rather as being "cast into a category with associated characteristics or features'. In terms of "Othering" they were ascribed the group categorisation of 'makwerewere'. A further subcategorisation process occurred within this group category and was based on 'Shades of Blackness', which further negatively influenced many immigrant students' formation of social identities and their sense of belonging to groups. Students who come from Congo, Zambia, Somalia, Malawi are naturally darker skinned than indigenous African learners. According to one of the principals,

They say this is a terrible thing which is part of our country, how dark the person is, because now South African students identify and discriminate against black immigrant students on the basis of darkness of skin colour because they say that person's too dark to be South African. This places the immigrant child under much stress and the child feels isolated. 
Some immigrant student responses in this regard,

They use my surname Dakkar to mock at me and they say I am dark. I am a makwerekwere and I must go back to Zambia.

They say you are black, like you are black more than other learners; you must be Congolese or maybe you from Somalia?

There was this one time we were arguing with some other people. So they were dissing me [slang - insult someone] and so I also dissed them and they say I'm dark. I must go back to Malawi and stuff.

Fifth, in order to counteract the social representation of being a foreigner, and to seek a sense of inclusion, many black [African] immigrant students forged a 'continental identity' to create a sense of solidarity with local black students. Thus, their identities became subjected to a process of evolution and modification within the new social context. There seemed to be an increasing emphasis on an 'African' identity,

In Zimbabwe, I was a Zimbabwean, but now they say Unapa is a makwerewere. That's not who I am. I am an African from Zimbabwe (Unapa, Zimbabwean).

I'm a Congolese girl from the DRC. They say I am a foreigner; a makwerewere and they push me and say 'Go back to your country'. I don't see myself as a foreigner. I am an African from Africa (Jeanette, DRC).

Andrew was resolute in his thinking and preferred to present himself in relation to others in terms of a continental perspective. Since the context within which he now found himself, forced him to be classified according to colour, he vehemently denied being 'black', instead he argued

I do not classify myself as 'black' according to South African racial categories. I am 'coffee brown'. I am an African since like them [South Africans] I too am from the continent of Africa. How can they [South Africans] call me a makwerekwere? (Andrew, Ghana).

And sixth, immigrant student self-agency was twofold in nature. They not only wanted to improve their own condition as much of the literature in the field reports, but there seemed to be an inherent drive to improve the human condition of others. There was genuine concern and a form of empathy. They wanted to assist indigenous black students in the spirit of 'brotherhood' [we are the same we are all 'Africans'] to improve the moral, academic and social fibre of South African society.

I see a kind of deficiency in the attitude of learners. For me, this is something that I can use to build the school into a better school and make the learners see that what they are doing is wrong. The South African government is giving the youth too many rights. I mean like already at the age of 12 you can have an abortion. That is just wrong in the bible and it is wrong as a person (Chanda, Zambia).

I can't say we really different, we look more or less the same except I am slightly lighter in colour then them but where we are different is in the attitude. The only difference is attitude. I'll change them. I will want them to understand what education is really about and how to treat elders. They must really get to understand that (Kevin, Zimbabwe).

The black people the way they treat people. I don't think we treat people the same way. I'd like to teach them about respect and how to treat people well (Athailiah, Mozambique).

\section{Analysis and discussion of findings}

\subsection{Psychosocial passing}

The aspect of psychosocial passing was to a large extent one of separation, under the guise of assimilation. It was in the interest of immigrant students to 'pass' as local Black students because of the political status of the host country. However, these immigrant students were prepared to do this only in terms of appearance and the benefits that they might accrue from such an association. They were not prepared to forsake their culture to adopt the dominant culture. For many immigrant students the host country represented a site of contamination and shame. They did not want to be associated with the behaviour and moral conduct of local Black students. Their adaptation took the form of separation whereby they maintained their culture and did not adopt the culture of the dominant group. Arguably learning the lingua franca of the host country could be seen as a slight form of assimilation, and an attempt at integration but this was merely a form of empowerment and to 'fit in and communicate with local Black students'. It was not an attempt at 'assimilation' or 'ethnic flight'.

\subsection{Skin pigmentocracy not an identifier}

The absence of an apartheid history characterised by heightened sensitivity to skin colour allowed many immigrant students to identify themselves according to other variables. As a researcher who was born during the apartheid era, my initial reaction to this response was one of disbelief, fascination and finally envy. I waited with bated breath to hear the word 'Black' as an identifier, escape from the lips of my many respondents. However, this did not happen. As South Africans we so readily categorise ourselves according to the imposed racial stratifications of the apartheid regime that it is difficult to break through the psychological shackles of apartheid. The only difference now is that these past racial stratifications have permutated to assume the form of a hyphenated identity with the new prefix "South African". For example, "South African - Indian"; "South African - Xhosa speaking" and so forth. I silently wished that I could eradicate years of defining my being by an imposed identity namely, "Indian". It was refreshing to note that Black immigrant youth were 'free' from such historical bondage. Immigrant students spoke of their identities in terms of personal attributes such as personality, and physical features, and social attributes such as culture, language, tradition, customs, ethnicity and land of origin.

\subsection{Hyphenated identities}

Many Black immigrant students experienced challenges in forming their identity in their very different home and school environments. They experienced difficulty in reconciling the expectations placed upon them by their traditional culture and those that hail from South Africa, or the Eurocentric culture generally found in South African school settings. They thus took on hybrid and hyphenated identities as a measure of reconciling these disparate cultural streams. However, the hyphen assumed a skewed formation, as many black immigrant students heavily leaned on their ethnic identities that provided the foundation of their cultural, social and moral mores. This seemed to comply with Hall's (Grossberg, 1996, 1997) figure of 'Difference' whereby the black immigrant student was constructed as an 'adversarial space' living in 'anxiety of contamination by its other' (Huyssen, 1986: vii). Images of a 'third space' (Bhabha, 1990, 1994), literally of defining an 'in-between place inhabited by immigrant students. And, images of 'border-crossing', that mark an image of 'between-ness' out of which identities are produced seemed to be the favoured options. 


\subsection{Imposed identities}

The influence of race and the effects of racism on black immigrant students were glaringly visible in this research study. Black immigrants were racialized as Black and were, therefore, subjected to the same racial prejudices and discrimination as their indigenous Black counterparts. The homogeneous categorisation of Blacks ignores the important national, ethnic, linguistic, cultural, political, and even racial differences that exist within the population. In particular, homogenous descriptions ignore the fact that for many Black immigrant youth, racial and ethnic identities are fluid and complex, thus many do not strictly identify with the rigid and dichotomous Black/White constructs through which racial and ethnic identities are based in South Africa.

The multiplicity of identities and of positions within any apparent identity as characteristic of Hall's (Grossberg, 1996, 1997) figure of 'fragmentation' was evident in the manner in which immigrant student identities manifested themselves. Black immigrant students were ascribed identities, namely 'makwerekwere', 'black' and were further cast into categories according to 'Shades of Blackness'. Furthermore, they were ascribed identities according to the country of origin, namely Nigerians were categorised as thieves, womanisers, drug lords, and people who were unhygienic. Zimbabweans were ostracised because of the perception that they came from a poverty-stricken country that lacked resources and a country that would seem to be 'uncivilised' and 'backward'.

South African society has for so long been organised along racial lines that it would seem that the only natural reaction to this newfound threat was to create imposed identities in an attempt to distinguish between 'them' and 'us'. Black immigrant students did not classify themselves or speak about their identities in terms of the abovementioned categories. They however claimed that "it is only when [they] came to South Africa that [they] realized that they got another label, now I am a Black". Most of these students realised that they looked very similar in appearance to local Black students and did not object to being called 'Black'. They tried to adapt to this newfound label more for personal gain and did not really identify with this label. The dominating identity remained their ethnic identity. The imposed identity 'Black' was a form of assimilation by 'the Other' - local black students - it was to some extent a form of involuntary assimilation on the part of the immigrant student. Immigrant students realised that it would be in there interest to accept the label 'Black' rather than be categorised as 'Makwerekwere'. It became clear that broader social spaces of South Africa were influencing dynamics on the school grounds. The data capture of this research study occurred at the height of the 2008 xenophobic attacks. Much of the xenophobic sentiments spilled into schools. This would account for the labelling of immigrant students as 'Makwerekwere'.

\subsection{Continental identities}

In contrast with the literature that advocates for a 'global identity', many Black immigrant students did not affiliate with this form of identity. Instead there was a very strong association with a "Continental identity". Almost all Black immigrant students strongly identified with the term "African" and justified this term by claiming that they came from the continent of Africa. This was a means of finding some common ground with the local Black students, whom they affiliated to in terms of physical appearance "I am an African since like them [South Africans] I too am from the continent of Africa". It was also a way of establishing territory and finding a sense of belonging and a niche in the host country.

\subsection{Self-agency}

As reported in the literature, immigrant student self agency and determination to succeed in their studies came out very strongly in this study as well. However, what was different from the literature was immigrant students' inherent drive to improve the human condition of others. There seemed to be genuine empathy and a collective sense of 'brotherhood' from Black [African] immigrant students with local Black students, and the forging of a common identity in terms of "we are African" - all from the continent of Africa. Almost all immigrant students had a strong religious affiliation and there seemed to be on a kind of mission to uplift and to restore the dignity and morality of their 'South African brothers'. This finding is something new in the literature. Furthermore, it would seem that this is a form of reverse integration where the immigrant student maintains his/her own culture and attempts to get the local Black students to adopt pertinent aspects of immigrant culture.

\subsection{Identity pathways}

The identity pathways of immigrant students leaned more towards the bicultural and transcultural styles of adaptation. None of the black immigrant students willingly chose to attempt to symbolically and psychologically dissemble and gain distance from their families and ethnic groups, nor did they opt for an adversarial style that centred on rejecting institutions of the dominant culture. They reject the norms and values of South African culture; they just do not actively act out against it.

\section{Conclusion}

As a dominant global player, South Africa is no longer an isolated country resilient to trans-national changes. Consequently, 'transnationalism' and 'transnational social spaces' - the whole terrain of interlocking transnational relationships and networks (Glick Schiller and Fouron, 1999:344) are currently informing and influencing the ever-shifting identities of immigrant youth. The focus is on the role of social networks and cross-border linkages in precipitating, reinforcing and entrenching transnational migration and eventually integration.

In direct contrast to the assimilation hypothesis that sees migrants as casting off the old and absorbing the new, this study has revealed that identity must be seen as one of hybridity, where immigrants take on a multiplicity of identities that are a combination of home and host (Hall, 1996; Bhabha, 1990; Rouse, 1992; Bondi, 1993; Basch et al., 1994; Mitchell, 1997; Smith and Guarnizo, 1998). Success does not depend so much on abandoning their culture and language to embrace another society as on preserving their original cultural endowment, while adapting instrumentally to a second" (Portes et al., 1999:129).

Processes such as migration, Diaspora formation and cultural hybridisation have transformed individual and group identities, and created "new ethnicities". Rather than being fixed and essentialised, these new forms of cultural identity are contingent and fluid (Hall, 1992, 1996; Hoogvelt, 1997). The Diaspora experience was very evident in this study, in the way immigrant students recognised the necessary heterogeneity and diversity; by a conception of 'identity' which lives with and through, not despite, difference, by hybridity. Immigrant students constantly produced and reproduced themselves anew, through transformation and difference, as evident from their shifting and new identities namely, their continental and hyphenated identities.

For these students, the formation of their identities was to a large extent shaped by the historical, political and social contexts in which they were located. The complex and constant interplay 
between the exclusionary conditions of a social structure that was marked by race (Black, Makwerekwere) and the psychological and cultural strategies employed by immigrant students (Continental identity, Hyphenated identity) to accommodate themselves to every indignities as well as to resist them, witnessed what Du Bois (1903) termed a sense of 'double consciousness' of immigrant students. They identified themselves according to what they perceived to be the way in which others identified them - the racial categorisations of the host country namely, "Black" or "Indian". However, these identifications were merely a way of adapting to the host country. Black immigrant students did not internalise these categorisations. It was not part of their self-identification. Rather, it was a form of an 'imposed identity'. They remained true to their ethnic origin and preferred to be identified by their ethnic identity that was hyphenated by the term "South African".

Schools and other social spaces are a significant locus where different cultural forms interact. Negotiating issues of identity, language and power is critical in the South African context. Schools should promote democracy through maximising opportunities for dialogue. This requires that minority voices such as black immigrant students be given opportunities for expression and that conscious efforts are made to dismantle the barrier of racism, which inhibits participation.

It has become apparent that students are constructing new transnational and cultural identities and actively working towards a South Africa where, "the spirit of Ubuntu - that profound African sense that we are human only through the humanity of other human beings - is not a parochial phenomenon, but [adds] globally to our common search for a better world" (Cryws-Williams, 1997:82).

The significance of this research in relation to international development issues and in a broader global context lies in the fact that most countries in the world face challenges of immigrant students and their shifting identifications. This study provides a glimpse of how Black immigrant youth are currently engaging with issues of race, identities, culture and ethnicity. Despite its concentration on the situation in South Africa, it has significance for the way in which education and life choices are conceived elsewhere in the world.

\section{References}

Arnett, J.J., 2002. The psychology of globalisation. American Psychologist 57 (10), 774-783.

Aronowitz, M., 1984. The social and emotional adjustment of immigrant children A review of the literature. International Review of Migration 18, 237-257.

Basch, Glick Schiller, L., Szanton-Blanc, N.C., 1994. Nations Unbound: Transnational Projects, Postcolonial Predicaments and Deterritorialized Nation-states. Gordon and Breach, New York.

Berry, J.W., 1980. Social and cultural change. In: Triandis, H.C., Brislin, R. (Eds.), Handbook of Cross-cultural Psychology, vol. 5. Allyn \& Bacon, Boston, pp. 211279.

Berry, J.W., 1997. Immigration, acculturation, and adaptation. International Journal of Applied Psychology 46, 5-34.

Berry, J.W., 1974. Psychological aspects of cultural pluralism: unity and identity, reconsidered. Topics in Culture Learning 2, 17-22.

Bhabha, H.K., 1994. The Location of Culture. Routledge, London Books.

Bhabha, H.K., 1990. Nation and Narration. Routledge, London and New York.

Bondi, L., 1993. Locating identity politics. In: Keith, M., Pile, S. (Eds.), Place and Politics of Identity. Routledge, New York.

Bouillon, A., 1998. New African immigration to South Africa. CASAS, Cape Town.

Coplan, D., 2008. Crossing borders. In: Hassim, S., Kupe, T., Worby, E. (Eds.), Go Home or Die Here. Violence, Xenophobia and the Reinvention of Difference in South Africa. Wits University Press, Johannesburg.

Crush, J., McDonald, D.A., 2000. Transnationalism African immigration, and new migrant spaces in South Africa. Canadian Journal of African Studies 31 (91), 119.

Cryws-Williams, J. (Ed.), 1997. In the Words of Nelson Mandela: A Little Pocketbook. Penguin Books, Parktown.

De la Hunt, L., 1998. Refugees and immigration law in South Africa. In: Crush, J. (Ed.), Beyond Control: Immigration and Human Rights in a Democratic South Africa. IDASA Publishing, Cape Town.
De Vos, G., 1980. Ethnic adaptation and minority status. Journal of Cross-Cultural Psychology 11 (1), 101-125.

Dion, K.K., 2006. On the development of identity: perspectives from immigrant families. In: Mahalingham, R. (Ed.), Cultural Psychology of Immigrants. Lawrence Erlbaum Associates, Publishers, Malwah, NJ, pp. 299-314.

Du Bois, W.E.B., 1903. Souls of Black Folk. Barnes \& Noble Inc., New York.

Essed, P., 2002. Everyday Racism: a new approach to the study of racism. In: Essed, P., Goldberg, D.T. (Eds.), Race Critical Theories: Text and Context. Blackwell Publishing Ltd., Australia.

Erickson, E., 1968. Identity Youth and Crisis. Norton, New York.

Falicov, R., 2002. Stories of Identity: Religion Migration and Belonging in a Changing World. Facing History and Ourselves Foundation, Inc., MA.

Garcia-Coll, C., Magnuson, K., 1997. The psychological experience of immigration: a developmental perspective. In: Booth, A., Crouter, A., Landale, N. (Eds.), Immigration and the Family Research and Policy on US Immigrants. Lawrence Erlbaum Associates, Publishers, Malwah, NJ.

Gauteng Department of Education, 2008. Ten Day Statistics.

Glick Schiller, N., Fouron, G., 1999. Terrains of blood and nation: Haitian transnational social fields. Ethnic and Racial Studies 22 (2), 217-237.

Grossberg, L., 1997. Cultural Studies: What's in a Name? Bringing it All Back Home: Essays on Cultural Studies. Duke University Press, Durham, pp. 252253.

Grossberg, L., 1996. Identity and cultural studies - is that all there is? In: Hall, S., du Gay, P. (Eds.), Questions of Cultural Identity. Sage Publications, London, pp. 87107.

Hall, S., 1996. Introduction: who needs identity? In: Hall, S., du Gay, P. (Eds.), Questions of Cultural Identity. Sage Publications, London, pp. 1-17.

Hall, S., 1992. 'New Ethnicities' race culture and difference. In: Rattansi, A., Donald, J. (Eds.), Muslims in Western Europe. Edinburgh University Press, Edinburgh, pp. 278-292.

Hassim, S., Kupe, T., Worby, E., 2008. Go Home or Die Here. Violence, Xenophobia and the Reinvention of Difference in South Africa. Wits University Press, Johannesburg.

Helms, J.E., 1990. Toward a model of White racial identity development. In: Helms, J.E. (Ed.), Black and White Racial Identity: Theory, Research, and Practice, Westport. Greenwood Press, CT, pp. 67-80.

Hoogvelt, A., 1997. Globalisation and the Postcolonial World: The New Political Economy of Development. Macmillan, Basingstoke.

Huyssen, A., 1986. After the Great Divide: Modernism, Mass Culture Postmodernism: Theories of Representation and Difference. Indiana University Press, USA

Klotz, A., 2000. Migration after apartheid: deracialising South African foreign policy. Third World Quarterly 21 (5), 831-847.

Marcia, J., Waterman, A., Matteson, D., Archer, S., Orlofsjky, J., 1993. Ego Identity: A Handbook of Psychosocial Research. Springer-Verlag, New York.

Marcia, J.E., 1980. Identity in adolescence. In: Adelson, J. (Ed.), Handbook of Adolescent Psychology. John Wiley and Sons, New York, pp. 159-187.

Marcia, J.E., 1966. Development and validation of ego identity status. Journal of Personality and Social Psychology 3 (5), 551-558.

Maestes, M., 2000. Acculturation and Ethnic Identity Measures for Latinos and Asian Americans: Analyses of Methodology and Psychometrics. University of Nebraska, Lincoln.

Mayring, P., 2000. Qualitative Content Analysis. Forum for Qualitative Research: Qualitative Social Research [On-line Journal], 1 (2). Available at: http://qualitative-research.net/fqs/fqs-e/2-00inhalt-e.htm (accessed 26.03.10).

Merriam, S.B., 1998. Qualitative Research and Case Study Applications in Education, Rev. ed. Jossey-Bass, San Francisco, CA.

Mitchell, K., 1997. Transnational discourse: bringing geography back in. Antipode 29 (2), 101-114.

Miles, M.B., Huberman, A.M., 1994. Qualitative Data Analysis: An Expanded Sourcebook, 2nd ed. Sage, London \& Thousand Oaks, CA.

Murrell, P.C., 1999. Class and race in negotiating identity. In: Garrod, A., Ward, J. Robinson, T., Kilkenny, R. (Eds.), Souls Looking Back: Life Stories of Growing up Black. Routledge, USA, pp. 3-14

Nesdale, D., Rooney, R., Smith, L., 1997. Migrant ethnic identity and psycho-logical distress. Journal of Cross Cultural Psychology 28, 569-588.

Parham, T.A., 1989. Cycles of psychological nigrescence. The Counselling Psychologist 17 (2), 187-226.

Peberdy, S., Crush, J., 1998. Trading Places: Cross-border Traders and the South African Informal Sector SAMP Migration Series No. 6. Kingston, Cape Town.

Phinney, J.S., Ong, A.D., 2007. Ethnic identity development in immigrant families. In: Lansford, J.E., Deater-Deckard, K.D., Bornstein, M.H. (Eds.), Immigrant Families in Contemporary Societies. Guilford Press, New York, pp. 137-156.

Portes, A., Guarnizo, L., Landolt, P., 1999. The study of transnationalism: pitfalls and promise of an emergent research field. Ethnic and Racial Studies 22 (2), 447462.

Ramphele, M., 1999. Immigration and Education: International Students at South African Universities and Technikons SAMP Migration Policy Series No. 12 Kingston, Cape Town.

Robinson, T.L., 1999. The intersections of identity. In: Garrod, A., Ward, J.V., Robinson, T.L., Kilkenny, R. (Eds.), Souls Looking Back: Life Stories of Growing up Black. Routledge, USA, pp. 85-98.

Rogerson, C., 1997. African immigrant entrepreneurs and Johannesburg's changing inner city. Africa Insight 27 (4), 265-273.

Rouse, R., 1992. Making sense of settlement: class transformation, cultural struggle and transnationalism among Mexican migrants in the United States. In: Glick 
Shiller, N., Basch, L., Blanc-Szanton, C. (Eds.), Towards a Transnational Perspective on Migration. New York Academy of Sciences, New York, pp. 25-52.

Saasa, 1996. Migration and the brain drain. In: Maasdorp, G. (Ed.), Can South and Southern Africa become Globally Competitive Economies? St. Martin's Press, New York, pp. 97-117.

Sandelowski, M., 2000. Focus on Research Methods Whatever happened to qualitative description? Research in Nursing and Health 23, 334-340.

Sirin, S.R., Fine, M., 2008. Muslim American Youth: Understanding Hyphenated Identities through Multiple Methods. New York University Press, New York.

Smith, M., Guarnizo, L., 1998. Transnationalism from Below. Transaction Publishers, New Brunswick, NJ.

Suarez-Orozco, C., 2004. Formulating identity in a globalized world. In: SuarezOrozco, M.M., Qin-Hilliard, D.B. (Eds.), Globalization, Culture and Education in the New Millennium. University of California Press, Ltd., London.

Suarez-Orozco, C., Suarez-Orozco, M.M., 2001. Children of Immigration. Harvard University Press, Cambridge, MA

Suarez-Orozco, M.M., 2000. Identities under siege: immigration stress and social mirroring among the children of immigrants. In: Robben, A.C.G., Suarez-Orozco,
M.M. (Eds.), Cultures Under Siege: Collective Violence and Trauma. Cambridge University Press, pp. 285-297.

Suarez-Orozco, C., Suarez-Orozco, M., 1995. Transformations: Migration, Family Life and Achievement Motivation Among Latino Adolescents. Stanford University Press, Palo Alto, CA.

Suarez-Orozco, M.M., 1989. Central American Refugees and U.S. High Schools A Psychosocial Study of Motivation and Achievement. Stanford University Press, Stanford, CA.

Tatum, B.D., 1997. Why are all the Black Kids Sitting in the Cafeteria? And Other Conversations About Race. Basic Books, New York

Taylor, C., 1994. Multiculturalism: Examining the Politics of Recognition. Princeton University Press, Princeton.

Verryn, B.P., 2008. Foreword. In: Hassim, S., Kupe, T., Worby, E. (Eds.), Go Home or Die Here. Violence, Xenophobia and the Reinvention of Difference in South Africa. Wits University Press, Johannesburg.

Waters, M., 1990. Ethnic Options: Choosing Identities in America. University of California Press, Berkley.

Wu, F.H., 2002. Yellow: Race in America Beyond Black and white. Basic Books, New York. 